\title{
The physiological response of reef corals to diel fluctuations in seawater temperature
}

\author{
Hollie M. Putnam *, Peter J. Edmunds \\ Department of Biology, California State University, 18111 Nordhoff Street, Northridge, CA 91330-8303, USA
}

\section{A R T I C L E I N F O}

\section{Article history:}

Received 12 July 2010

Received in revised form 27 October 2010

Accepted 27 October 2010

\section{Keywords:}

Coral

Fluctuation

Pocillopora meandrina

Porites rus

Temperature

\begin{abstract}
A B S T R A C T
An opportunity to explore the effects of fluctuating temperatures on tropical scleractinian corals arose when diurnal warming (as large as $4.7^{\circ} \mathrm{C}$ ) was detected over the rich coral communities found within the back reef of Moorea, French Polynesia. In April and May 2007, experiments were completed to determine the effects of fluctuating temperature on Pocillopora meandrina and Porites rus, and consecutive trials were used to expose them for 13 days to $26^{\circ} \mathrm{C}, 28^{\circ} \mathrm{C}$ (ambient conditions), $30^{\circ} \mathrm{C}$, or a fluctuating treatment ranging from 26 to $30{ }^{\circ} \mathrm{C}$ over $24 \mathrm{~h}$. The multivariate response was assessed using maximum dark-adapted quantum yield of PSII $\left(\mathrm{F}_{\mathrm{V}} / \mathrm{F}_{\mathrm{M}}\right)$, Symbiodinium density, chlorophyll-a content, and calcification. In trial 1, multivariate physiology of both species was significantly affected by treatments, with the fluctuating temperature resulting in a $17-45 \%$ decline in Symbiodinium density (relative to the ambient) matching that occurring at a constant $30^{\circ} \mathrm{C} ; \mathrm{F}_{\mathrm{V}} / \mathrm{F}_{\mathrm{M}}$, chlorophyll-a content, and calcification, did not differ between the fluctuating and the steady treatments. In contrast, in trial 2 that utilized corals collected two weeks after those used in trial 1 , the corals were unaffected by the treatments, likely due to an environment $\times$ trial interaction caused by seasonal declines in Symbiodinium density. Together, these results demonstrate that short transgressions to ecologically relevant high and low temperatures can elicit a potentially detrimental response equivalent to that occurring upon exposure to a constant high temperature. The dissimilar responses among dependent variables and consecutive trials underscore the importance of temporal replication and multivariate approaches in coral ecophysiology. It is likely that recent history has a stronger effect on the response of corals to treatments than is currently recognized.
\end{abstract}

(C) 2010 Elsevier B.V. All rights reserved.

\section{Introduction}

The magnitude, duration, and rate of increase in seawater temperature can all negatively impact corals (Coles and Jokiel, 1977; Hoegh-Guldberg and Smith, 1989; Jokiel and Coles, 1990; Dunn et al., 2004; Middlebrook et al., 2010), but it is uncertain where, when, and how a particular temperature metric will emerge as an important driver of coral stress. Therefore, it is important for studies of thermal bleaching to characterize the complete range of biologically relevant temperature metrics in order to fully understand the causes (Fitt et al., 2001). One example of the benefits of such an approach comes from Puerto Rico, where a combination of temperature metrics - rather than simply the maximum seawater temperature, and the duration of exposure to this value (Gleeson and Strong, 1995) - provided the best predictor of coral bleaching between 1966 and 1995 (Winter et al., 1998). Similarly, off the coast of East Africa, coral bleaching was associated with degree heating weeks, degree heating months, and the variability as assessed by the standard deviation and kurtosis of the monthly mean records of sea surface temperature (SST) (McClanahan et al., 2007). Together, studies such

\footnotetext{
* Corresponding author. Present address: Hawaii Institute of Marine Biology, School of Earth and Science and Technology, University of Hawaii, 46-007 Lilipuna Rd, Kaneohe, HI 96744, USA. Tel.: +1 808236 7427; fax: +1 8082367443.

E-mail address: hputnam@hawaii.edu (H.M. Putnam).
}

as those of Winter et al. (1998) and McClanahan et al. (2007) indirectly suggest that the thermal history of a coral matters a great deal in determining its response to thermal stress.

Several experimental studies have suggested that the role of temperature in coral bleaching may not lie only in the threshold value eliciting the response, but also the sublethal intensities that create the potential for acclimatization (McClanahan and Maina, 2003; Middlebrook et al., 2008; Edmunds, 2009). For instance, the rate of change in temperature and the capacity for acclimatization influence the ways in which corals respond to elevated temperature (Coles and Jokiel, 1977; Brown et al., 2002; D'Croz and Maté, 2004; Castillo and Helmuth, 2005), with one of the best examples of these effects coming from intertidal corals in Thailand. In this location, Goniastrea aspera that were emerged at low tide and exposed to high light intensities from January to March subsequently displayed acquired resistance (i.e., acclimatization) 2-5 months later to elevated seawater temperatures, most likely as a result of increases in cellular defenses in the cnidarian host (Brown et al., 2002). Similarly, for sub-tidal corals, their physiological response to increased temperature can be ameliorated by their temperature history (Castillo and Helmuth, 2005; Middlebrook et al., 2008; Edmunds, 2009).

The widespread use of remotely sensed SST to characterize seawater temperatures, specifically those associated with coral bleaching (e.g., Gleeson and Strong, 1995) may not detect aspects of the underwater thermal regime that are also important to corals (Brown, 1997b; Leichter 
et al., 2006; Sheppard, 2009). Critically, SST in reef environments routinely differs from underwater measurements by as much as $\approx 3{ }^{\circ} \mathrm{C}$ (Leichter et al., 2006), and sub-surface temperatures are more dynamic over short periods. For instance, underwater temperature fluctuates rapidly (i.e., up to $\sim 5{ }^{\circ} \mathrm{C}$ in $<24 \mathrm{~h}$ ) throughout the Florida Keys, the Bahamas, St. Croix, Belize, and Bonaire (Leichter et al., 2006), largely as a result of diurnal warming in shallow water $(10 \mathrm{~m})$, and tidal forcing and internal waves at greater depths (20-30 m). Daily fluctuations as large as $10{ }^{\circ} \mathrm{C}$ also affect the near-shore, shallow reefs of Oman and Taiwan (Coles, 1997; Lee et al., 1999), and daily fluctuations of $\sim 6{ }^{\circ} \mathrm{C}$ are common in the lagoon and over fringing reefs (1-10 $\mathrm{m}$ depth) in American Samoa and other Pacific islands (Brown, 1997b; Craig et al., 2001). SST records can also miss more subtle characteristics of the thermal environment affecting corals, notably the variation in temperature of individual colonies due to their color and the ways in which seawater flows around them (Fabricius, 2006; Jimenez et al., 2008).

Lagoon and back reef environments provide interesting locations for studying the response of corals to complex thermal signals, because they are often characterized by rich coral communities in temperature regimes that fluctuate with a high frequency and magnitude (Craig et al., 2001; Sheppard, 2009; Edmunds et al., 2010). Such fluctuations occur within a context that may already place the mean habitat temperatures close to the upper thermal limit for corals (Brown, 1997a), at least during the summer, and this effect is likely to intensify as global temperatures continue to rise (IPCC, 2007). The back reef of Moorea, French Polynesia, is representative of this type of thermal regime (see also Birkeland et al., 2008), and in this location mean seawater temperature reaches $32{ }^{\circ} \mathrm{C}$ in summer, and adjacent to the benthos at 2-3 $\mathrm{m}$ depth, temperature varies diurnally by $0.2^{\circ} \mathrm{C}$ to $4.7^{\circ} \mathrm{C}$ (Edmunds et al., 2010, P.J. Edmunds unpublished data). Such an extreme thermal regime might be expected to be physiologically challenging to corals (Coles and Brown, 2003), yet healthy corals grow throughout this environment and cover as much as $33 \pm 2 \%$ of the benthos (in 2005 [P.J. Edmunds unpublished data]). With these observations as a context, in this study we used corals from the back reef of Moorea to test the hypothesis that their physiology is affected differentially by fluctuating versus steady temperatures. Our approach used two common corals - Pocillopora meandrina (Dana 1846) and Porites rus (Forskål 1775) - and tested their response to a combination of thermal regimes using four dependent variables selected to evaluate the impacts of the treatments on the coral host and the Symbiodinium symbionts.

\section{Methods}

As part of another study, seawater temperature in the back reef of Moorea was measured with loggers (HOBO Water Temp Pro, Onset Computer Corp. Bourne, Massachusetts, USA; accuracy $\pm 0.2{ }^{\circ} \mathrm{C}$ ) placed at 2-4 $\mathrm{m}$ depth at multiple locations (Edmunds et al., 2010, P.J. Edmunds unpublished data). The temperature records from these deployments revealed diurnal fluctuations, with a maximum daily range of $4.7^{\circ} \mathrm{C}$ and a mean daily range of $1.1^{\circ} \mathrm{C}$ (Fig. 1). These results were used to provide an ecological context for the design of the present manipulative experiments.

To test the effects of diurnal fluctuations in temperature on coral physiology, two experiments were completed in April and May 2007. Independent treatment replicates were obtained by completing two, 18-day trials ( 5 days acclimation and 13 days treatments), one beginning on April 10 (trial 1) and one beginning on April 26 (trial 2). Fragments ( 4-6 cm in length) of $P$. rus (Forskål, 1775) and $P$. meandrina (Dana, 1846) were collected from 2 to $4 \mathrm{~m}$ depth in the back reef, with only one branch collected from each colony, and one nubbin formed from each branch to increase the likelihood that unique genotypes were sampled. Fragments were transported to the Richard B. Gump South Pacific Research Station where they were formed into nubbins by attaching them to bases using underwater epoxy (A-788,
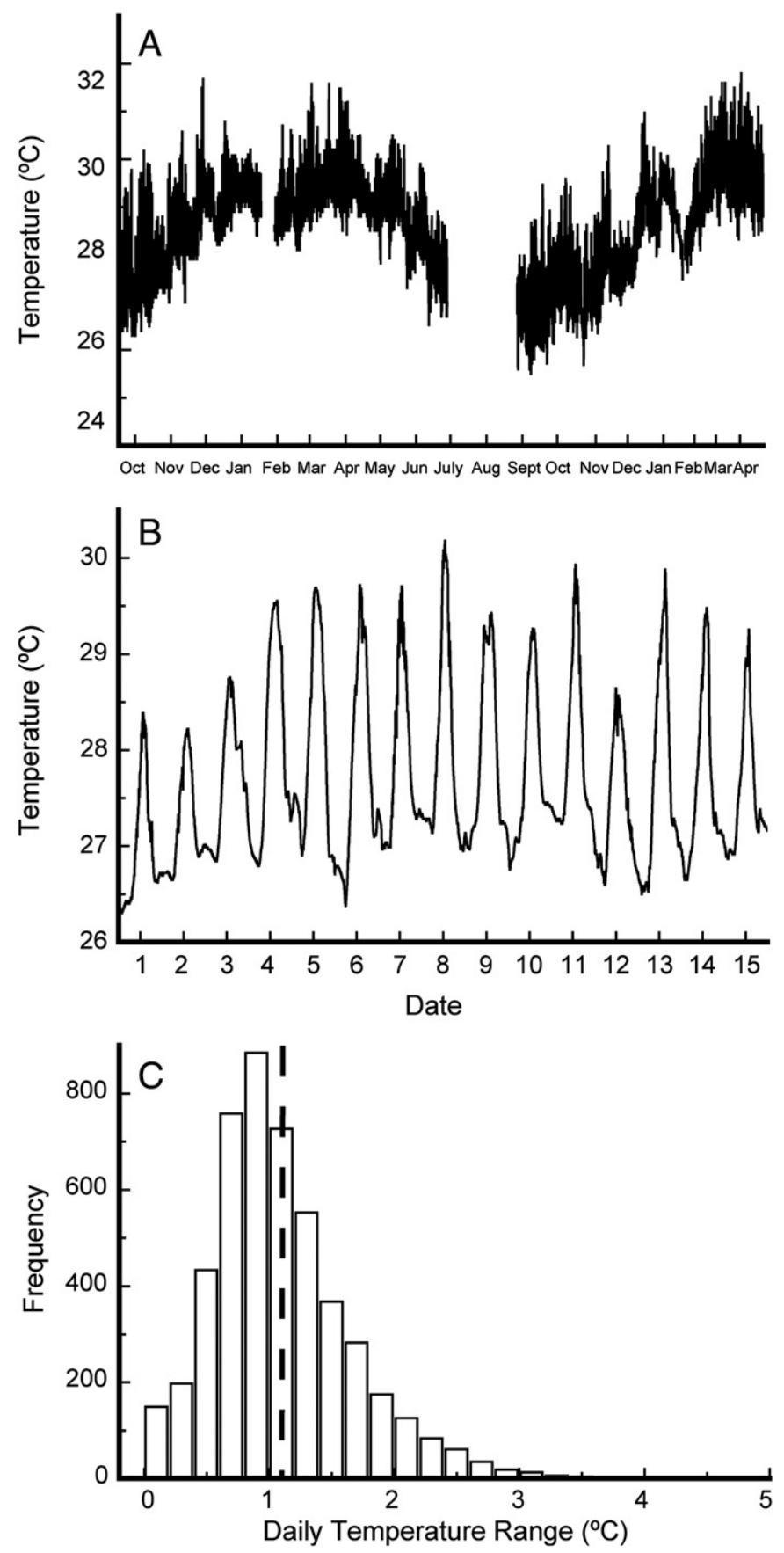

Fig. 1. Seawater temperature at 2-4 m depth in the back reef of Moorea. (A) Temperature at one representative site from October 2005 to April 2007; these data were recorded with a sampling interval of $10 \mathrm{~min}$ (Oct 05-Dec 06) and $15 \mathrm{~min}$ (Jan 07-April 07) and are plotted with the check marks on the abscissa corresponding to the first day of each month. (B) Temperature from a period of unusually strong daily fluctuation during October 2005; with peaks corresponding to midday solar warming, and minima occurring between 19:30 and 07:30. (C) Histogram of daily range in seawater temperature between October 2005 and April 2007. Values displayed are based on data collected with a sampling interval of 10 or $15 \mathrm{~min}$ (see above) at 10 sites. A daily range of $\sim{ }^{\circ} \mathrm{C}$ was measured with the greatest frequency (vertical dashed line), with a maximum daily range of $4.7^{\circ} \mathrm{C}(n=4878$ records).

Z-Spar Los Angeles, California, USA) and allowed to recover for $\sim 24 \mathrm{~h}$ in a re-circulating seawater. Following recovery, the nubbins were acclimated to the experimental conditions for 5 days at ambient temperature $\left(28^{\circ} \mathrm{C}\right)$ and light $\left(\sim 530 \mu \mathrm{mol}\right.$ photons $\left.\mathrm{m}^{-2} \mathrm{~s}^{-1}\right)$. The experimental incubations began after this period and lasted 13 days. To examine the effects of these treatments, response variables were assessed at the termination of the experiments. 
The temperature treatments were created in indoor microcosms consisting of four 135-L tanks, each with a separate chiller, heater, pump, and filter. The tanks were filled with seawater freshly collected from the outer reef, and this was continuously circulated and partially replaced ( $20 \%)$ daily. Each tank was fitted with a microprocessorcontrolled regulator (AquaController Jr., Neptune Systems, San Jose, California, USA) that maintained temperature with a resolution of $\pm 0.2^{\circ} \mathrm{C}$. These regulators were used to create steady treatments as well as a fluctuating treatment designed to mimic conditions within the back reef (Figs. 1 and 2). The experiment consisted of a control, a steady temperature close the annual mean temperature of the back reef $\left(28^{\circ} \mathrm{C}\right)$, and three treatments of: (1) fluctuating temperatures (26$30{ }^{\circ} \mathrm{C}$ over $24 \mathrm{~h}$ ), (2) a steady $26^{\circ} \mathrm{C}$, and (3) a steady $30^{\circ} \mathrm{C}$. In the oscillatory treatment, the tanks were maintained at $26^{\circ} \mathrm{C}$ between 00:00 and 06:00 h, increased to $28^{\circ} \mathrm{C}$ from 06:00 to 10:00, increased again to $30^{\circ} \mathrm{C}$ from $10: 00$ to $14: 00$, decreased to $28^{\circ} \mathrm{C}$ from $14: 00$ to $18: 00$, and finally decreased to $26^{\circ} \mathrm{C}$ at $18: 00$ and remained at this temperature until the following morning at $06: 00 \mathrm{~h}$, when the sequence was repeated. To assess the efficacy of the treatment, temperatures were logged at $1 \mathrm{~h}$ intervals throughout the experiment (Fig. 2).

While light and temperature are both causative factors in the coral bleaching (Fitt et al., 2001), it was not feasible to include light manipulations due to logistical constraints. Instead, incubations were completed at a single irradiance provided with lamps (Sylvania, Metalarc, $1000 \mathrm{~W}$ ) suspended above the tanks, with their height adjusted to provide light at $\sim 45 \%$ of the maximum light intensity at the collection depth (2-4 m); the reduced intensity ensured that the daily integrated light exposure was similar in the tanks and the field. The average maximum light intensity at noon on cloudless days in April was $1438 \pm 55 \mu \mathrm{mol}$ photons $\mathrm{m}^{-2} \mathrm{~s}^{-1}( \pm \mathrm{SE}, n=25$ over 2 days) and, therefore, the light in the incubation tanks was adjusted to $\sim 640 \mu \mathrm{mol}$ photons $\mathrm{m}^{-2} \mathrm{~s}^{-1}$ (all light measurements were taken with a Li-Cor ${ }^{\circledR} 4 \pi$ sensor [LI 193SA] attached to a LI $1400 \mathrm{~m}$ ). The lamps were operated on a $12 \mathrm{~h}$ light: $12 \mathrm{~h}$ dark cycle, commencing at 06:30 h, and the light in the tanks was measured multiple times each day using a $4 \pi$ sensor (LI 193SA).

\subsection{Symbiont response variables}

The effect of the treatment on Symbiodinium was assessed as maximum dark-adapted quantum yield of PSII ( $\mathrm{F}_{\mathrm{V}} / \mathrm{F}_{\mathrm{M}}$ [Genty et al., 1989]), which quantifies the efficiency of PSII (Jones et al., 1998; Warner et al., 1999). Decreases in $\mathrm{F}_{\mathrm{V}} / \mathrm{F}_{\mathrm{M}}$ can signal chronic photo-

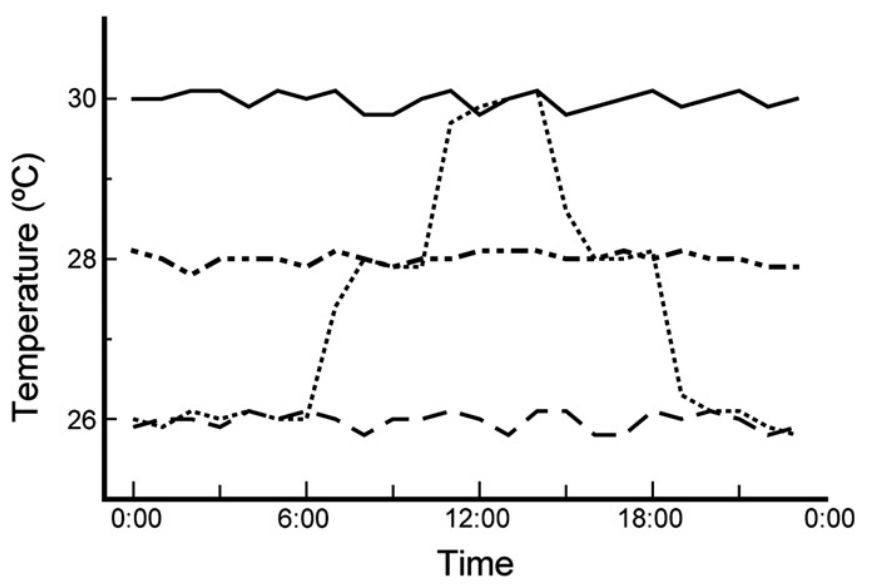

Fig. 2. A representative day (11 April 07) of seawater temperature in the four treatment conditions created in trial 1 ( solid black line $=30^{\circ} \mathrm{C}$, dotted and dashed line $=28^{\circ} \mathrm{C}$, dashed line $=26{ }^{\circ} \mathrm{C}$, and dotted line $=$ oscillating from $26{ }^{\circ} \mathrm{C}$ to $30{ }^{\circ} \mathrm{C}$ and back to $26^{\circ} \mathrm{C}$ ). Temperatures were recorded in each treatment with a frequency of $1 \mathrm{~h}$, and all treatments were maintained at the programmed temperatures with a SE of $<0.2{ }^{\circ} \mathrm{C}$ $\left(n=312\right.$ readings $\left.\operatorname{tank}^{-1}\right)$. Refer to text for further details. inhibition (damage to the photosynthetic apparatus), or reversible photoinhibition (Gorbunov et al., 2001). Fluorescence measurements were taken on the final night of treatments, using a Diving-PAM (Walz, GmbH, Effeltrich, Germany), after 2.5 h of darkness ( 21:00 h). To measure $\mathrm{F}_{\mathrm{V}} / \mathrm{F}_{\mathrm{M}}$, each coral was removed from its treatment tank in a darkened beaker $(500 \mathrm{~mL})$ filled with seawater, and a single measurement taken using the 5.5-mm diameter probe of the DivingPAM. To minimize variation in $\mathrm{F}_{\mathrm{V}} / \mathrm{F}_{\mathrm{M}}$ due to location of the probe or branch orientation, all measurements were taken $\sim 2 \mathrm{~cm}$ from the tip of each branch, with the probe held $1 \mathrm{~cm}$ above the tissue.

Corals nubbins were split in half for the analysis of Symbiodinium density and chlorophyll-a (chl-a) content. Half of each nubbin was fixed in formalin (5\% in seawater) and the remainder frozen at $-20^{\circ} \mathrm{C}$. To completely remove tissue from the skeleton to quantify Symbiodinium density, the skeleton of the fixed portion was dissolved in $10 \% \mathrm{HCl}$ (in fresh water), and the tissue layer homogenized using an ultrasonic dismembrator (Fisher 15-338-550) fitted with a $3.2 \mathrm{~mm}$ diameter probe (Fisher 15-338-67). This is especially important in perforate skeletons such as $P$. rus, where nondestructive methods such as waterpiking and airbrushing do not fully remove tissues. Six replicate counts of Symbiodinium in the homogenate were completed using a haemocytometer, and an aliquot of the slurry was dried at $60{ }^{\circ} \mathrm{C}$ to determine biomass. The Symbiodinium density was normalized to dry tissue biomass and expressed in units of cells $\mathrm{mg}^{-1}$.

To extract chlorophyll-a, the frozen portion of the nubbins was immersed in $100 \%$ acetone in the dark at $4{ }^{\circ} \mathrm{C}$ for $24 \mathrm{~h}$. The extract was centrifuged at $14,000 \mathrm{rpm}$ for $1 \mathrm{~min}$, and the supernatant removed for absorbance measurements at $630 \mathrm{~nm}$ and $663 \mathrm{~nm}$. To ensure full pigment extraction, this process was repeated for a second $24 \mathrm{~h}$ period. Chlorophyll concentration was calculated using the equations of Jeffrey and Humphrey (1975), and normalized to surface area of the fragments $\left(\mu \mathrm{g} \mathrm{cm}^{-2}\right)$ as estimated by aluminum foil (Marsh, 1970).

\subsection{Holobiont-related response variables}

To estimate changes in skeletal weight in response to treatments (i.e., calcification), corals were buoyant weighed $( \pm 1 \mathrm{mg}$; Davies, 1989) prior to manipulations, and immediately following the experiment. Changes in buoyant weight were converted to dry weight using an aragonite density of $2.93 \mathrm{mg} \mathrm{cm}^{-3}$ (Davies, 1989). Due to the necessity to divide samples for Symbiodinium density and chl-a following growth measurements, calcification was normalized to surface area $\left(\mathrm{mg} \mathrm{cm}^{-2} \mathrm{day}^{-1}\right)$ as estimated by the aluminum foil method (Marsh, 1970).

\subsection{Statistical analysis}

All experimental methods used in trial 1 were repeated for trial 2. Initially, the whole experiment was analyzed with a randomized block ANOVA, with factors of treatment (fixed), species (fixed), and trial (a random blocking factor); species was treated as a fixed factor as they were chosen to contrast an imperforate ( $P$. meandrina) and a perforate ( $P$. rus) coral. However, this design was subsequently modified because of a significant trial effect (Symbiodinium density $F=79.26, d f=1$, $P<0.0001 ; \quad F_{V} / F_{M} F=4.39, d f=1, P<0.05 ;$ chl-a $F=32.72, d f=1$, $P<0.0001$; and growth $F=8.04, d f=1, P<0.01$ ), which was evident despite the considerable effort taken to create identical treatments (Fig. 2, Table 1). Consequently, data were analyzed separately by trial with the nubbins treated as statistical replicates. While the experiment was therefore pseudoreplicated (Hurlbert, 1984) in each tank, it is likely that the individual nubbins were functionally independent because their aggregated biomass relative to the volume of seawater was exceedingly small (1: 3500). Moreover, the seawater was changed partially (20\%) every day, and daily repositioning of the corals in each tank was used to counteract any bias from a position effect. 
Table 1

Conditions recorded hourly in the four tanks during both trials. Values shown are mean \pm SE $(n)$ [coefficient of variation]. Fluctuating temperatures are calculated over the time spent at each temperature $\left(26^{\circ} \mathrm{C}, 28{ }^{\circ} \mathrm{C}\right.$, and $30^{\circ} \mathrm{C}$, see Fig. 2$)$.

\begin{tabular}{lll}
\hline Treatment & \multicolumn{2}{l}{ Temperature $\left({ }^{\circ} \mathrm{C}\right)$} \\
\cline { 2 - 3 } & Trial 1 & Trial 2 \\
\hline Acclimation period & $28.0 \pm 0.2(121)[0.4]$ & $28.0 \pm 0.2(93)[0.3]$ \\
Ambient (control) & $28.0 \pm 0.2(305)[0.4]$ & $28.0 \pm 0.2(303)[0.4]$ \\
Steady, low & $26.0 \pm 0.2(305)[0.4]$ & $26.0 \pm 0.2(305)[0.4]$ \\
Steady, high & $30.0 \pm 0.2(280)[0.3]$ & $30.0 \pm 0.2(305)[0.4]$ \\
Fluctuating & & \\
$\quad$ Mean $\left(28{ }^{\circ} \mathrm{C}\right)$ & $28.0 \pm 0.2(101)[1.3]$ & $28.0 \pm 0.2(99)[1.1]$ \\
Mean $\left(30^{\circ} \mathrm{C}\right)$ & $30.0 \pm 0.2(48)[0.6]$ & $29.9 \pm 0.2(47)[0.8]$ \\
Mean $\left(26{ }^{\circ} \mathrm{C}\right)$ & $26.1 \pm 0.2(155)[0.4]$ & $26.0 \pm 0.2(155)[0.5]$ \\
\hline
\end{tabular}

For each trial, a MANOVA was used to test for an overall effect of the treatments using all four measures of coral condition as response variables, fixed factors of treatment and species, and Pillai's Trace as the inferential statistic. Having completed a multivariate test of treatment effects that was protected from the risks of Type I error, univariate ANOVAs were used to identify the variable(s) driving the results, as well as the direction of effect; interaction terms were pooled with the residual error term when $P>0.25$ (Quinn and Keough, 2002). Even if the main effects were not significant in the MANOVA, subsequent univariate ANOVAs were conducted in order to support a qualitative contrast of the treatment effects in both trials. While all univariate ANOVAs are presented, statistical inferences are based only those factors significant in the multivariate analysis. Assumptions of parametric statistics were assessed through graphical analysis of the residuals following transformation of the data. All analyses were carried out using JMP 7.0 software (SAS Institute Inc.), and post hoc comparisons with Tukey's T' Method for unequal sample size (Sokal and Rohlf, 1995) were completed whenever the univariate test of main effects was significant.

\section{Results}

The treatment temperatures remained at target levels (all SE $\pm 0.2{ }^{\circ} \mathrm{C}$ ) throughout the experiment (Fig. 2) and were statistically identical in both trials (Table 1). Light levels averaged by day in trial 1 were $646 \pm 4 \mu \mathrm{mol}$ photons $\mathrm{m}^{-2} \mathrm{~s}^{-1}$, and for trial 2 were $636 \pm 6 \mu \mathrm{mol}$ photons $\mathrm{m}^{-2} \mathrm{~s}^{-1}$ (both \pm S.E., $n=12$ trial $^{-1}$ ), and did not differ between trials $(F=1.720, d f=1,22, P>0.05)$.

\subsection{Trial 1}

There was slight paling of coral tissue during the treatments, however, no necrosis or mortality was observed, and normal polyp expansion occurred throughout the experiment. MANOVA revealed that the overall response of the corals differed significantly among treatments, and between species, although there was no interaction between the two (Table 2).

\subsubsection{Symbiont-related response variables}

Following the treatments, the density of Symbiodinium ranged from 1.55 to $2.83 \times 10^{5}$ cells $\mathrm{mg}^{-1}$ for $P$. meandrina, and 2.67 to $3.21 \times 10^{5}$ cells $\mathrm{mg}^{-1}$ for $P$. rus, and was significantly affected by the treatments (Table 3 ). The largest reduction in the Symbiodinium density was seen in the fluctuating treatment and the $30{ }^{\circ} \mathrm{C}$ treatment for P. meandrina (Fig. 3), where mean density decreased $45 \%$ and $36 \%$, respectively, compared to the control $\left(28^{\circ} \mathrm{C}\right)$. There was a similar trend for $P$. rus, where mean Symbiodinium density showed the greatest decrease in the fluctuating treatment (17\%), compared to the control, although in this case the post hoc contrasts were not significant (Fig. 3). There was also a significant difference in Symbiodinium density between two species, with lower densities in
Table 2

Results of statistical analyses by MANOVA of physiology (Symbiodinium density, $\mathrm{F}_{\mathrm{V}} / \mathrm{F}_{\mathrm{M}}$, chl-a content, and calcification) of Pocillopora meandrina and Porites rus among the four treatments (Table 1 ) in trials 1 and 2.

\begin{tabular}{lllcrr}
\hline Trial & Source & Pillai's Trace & \multicolumn{1}{c}{$d f$} & \multicolumn{1}{c}{$F$} & \multicolumn{1}{l}{$P$} \\
\hline 1 & Treatment & 0.591 & 12,192 & 3.929 & $<0.001$ \\
& Species & 2.334 & 4,62 & 36.176 & $<0.001$ \\
& Treatment $\times$ Species & 0.261 & 12,192 & 1.528 & 0.117 \\
2 & Treatment & 0.254 & 12,195 & 1.505 & 0.125 \\
& Species & 3.680 & 4,63 & 57.953 & $<0.001$ \\
& Treatment $\times$ Species & 0.246 & 12,195 & 1.453 & 0.145 \\
\hline
\end{tabular}

P. meandrina (12-42\% across treatments), but there was no treatment $\times$ species interaction (Table 3 ).

$\mathrm{F}_{\mathrm{V}} / \mathrm{F}_{\mathrm{M}}$ was $\sim 8 \%$ higher in $P$. rus at the steady $26{ }^{\circ} \mathrm{C}$ treatment compared to control $(F=3.906, d f=3,79, P=0.012)$, but was unaffected by the fluctuating treatment (Fig. 4) in comparison to the control. Statistically, $\mathrm{F}_{\mathrm{V}} / \mathrm{F}_{\mathrm{M}}$ of $P$. meandrina was unaffected by the treatments, although there was a trend for an increase at $26{ }^{\circ} \mathrm{C}$ (Fig. 4). The main effect of species was also significant $(F=80.356, d f=1,79, P<0.001)$, but there was no treatment $\times$ species interaction (Table 3 ). The species effect for $\mathrm{F}_{\mathrm{V}} / \mathrm{F}_{\mathrm{M}}$ resulted from $\sim 10 \%$ higher values for $P$. meandrina $(0.62-$ $0.64)$ compared to $P$. rus $(0.55-0.60)$. The mean chl-a content in $P$. meandrina ranged from 1.6 to $2.6 \mu \mathrm{g} \mathrm{cm}^{-2}$ after treatment, and in P. rus from 3.3 to $4.2 \mu \mathrm{g} \mathrm{cm}{ }^{-2}$. Chlorophyll-a content was unaffected by the treatments, but it differed significantly between species, and was unaffected by the treatment $\times$ species interaction (Table 3 ). On average, chl-a concentrations were $\sim 2 \times$ lower in $P$. meandrina compared to $P$. rus (Fig. 4).

Table 3

Results of statistical analyses with univariate ANOVAs of each response variable from trial 1 (A) and trial 2 (B) for Pocillopora meandrina and Porites rus. The main effects of treatment and species are denoted as $\mathrm{T}$ and $\mathrm{S}$, respectively, and the interaction as $\mathrm{T} \times \mathrm{S}$. All non-significant $\mathrm{T} \times \mathrm{S}$ terms (at $P>0.25$ ) were pooled with the error term for significance testing (Quinn and Keough, 2002).

\begin{tabular}{|c|c|c|c|c|c|}
\hline & Source & $d f$ & MS & $F$ & $P$ \\
\hline \multicolumn{6}{|l|}{ (A) Trial 1} \\
\hline \multirow[t]{4}{*}{ Symbiodinium density } & $\mathrm{T}$ & 3 & 0.688 & 9.050 & $<0.001$ \\
\hline & $\mathrm{S}$ & 1 & 2.067 & 27.211 & $<0.001$ \\
\hline & $\mathrm{T} \times \mathrm{S}$ & 3 & 0.190 & 2.500 & 0.066 \\
\hline & Error & 72 & 0.076 & & \\
\hline \multirow{3}{*}{$\mathrm{F}_{\mathrm{V}} / \mathrm{F}_{\mathrm{M}}$} & $\mathrm{T}$ & 3 & 0.005 & 3.906 & 0.012 \\
\hline & $\mathrm{S}$ & 1 & 0.101 & 80.356 & $<0.001$ \\
\hline & Error & 79 & 0.001 & & \\
\hline \multirow[t]{4}{*}{ Chlorophyll-a } & $\mathrm{T}$ & 3 & 0.305 & 1.800 & 0.154 \\
\hline & $\mathrm{S}$ & 1 & 8.356 & 49.308 & $<0.001$ \\
\hline & $\mathrm{T} \times \mathrm{S}$ & 3 & 0.429 & 2.531 & 0.063 \\
\hline & Error & 75 & 0.169 & & \\
\hline \multirow{4}{*}{ Calcification } & $\mathrm{T}$ & 3 & 0.176 & 5.961 & 0.001 \\
\hline & $\mathrm{S}$ & 1 & 1.497 & 50.592 & $<0.001$ \\
\hline & $\mathrm{T} \times \mathrm{S}$ & 3 & 0.066 & 2.238 & 0.091 \\
\hline & Error & 73 & 0.030 & & \\
\hline \multicolumn{6}{|l|}{ (B) Trial 2} \\
\hline \multirow[t]{4}{*}{ Symbiodinium density } & $\mathrm{T}$ & 3 & 0.091 & 0.670 & $>0.05$ \\
\hline & $\mathrm{S}$ & 1 & 0.053 & 0.391 & $>0.05$ \\
\hline & $\mathrm{T} \times \mathrm{S}$ & 3 & 0.292 & 2.162 & $>0.05$ \\
\hline & Error & 74 & 0.135 & & \\
\hline \multirow[t]{4}{*}{$\mathrm{F}_{\mathrm{V}} / \mathrm{F}_{\mathrm{M}}$} & $\mathrm{T}$ & 3 & 0.001 & 0.410 & $>0.05$ \\
\hline & $\mathrm{S}$ & 1 & 0.222 & 171.220 & $<0.001$ \\
\hline & $\mathrm{T} \times \mathrm{S}$ & 3 & 0.002 & 1.784 & $>0.05$ \\
\hline & Error & 75 & 0.001 & & \\
\hline \multirow[t]{4}{*}{ Chlorophyll-a } & $\mathrm{T}$ & 3 & 0.711 & 3.739 & 0.014 \\
\hline & $\mathrm{S}$ & 1 & 3.513 & 18.476 & $<0.001$ \\
\hline & $\mathrm{T} \times \mathrm{S}$ & 3 & 0.288 & 1.517 & $>0.05$ \\
\hline & Error & 79 & 0.190 & & \\
\hline \multirow[t]{3}{*}{ Calcification } & $\mathrm{T}$ & 3 & 0.316 & 2.859 & 0.042 \\
\hline & $\mathrm{S}$ & 1 & 9.345 & 84.604 & $<0.001$ \\
\hline & Error & 80 & 0.110 & & \\
\hline
\end{tabular}


Trial 1
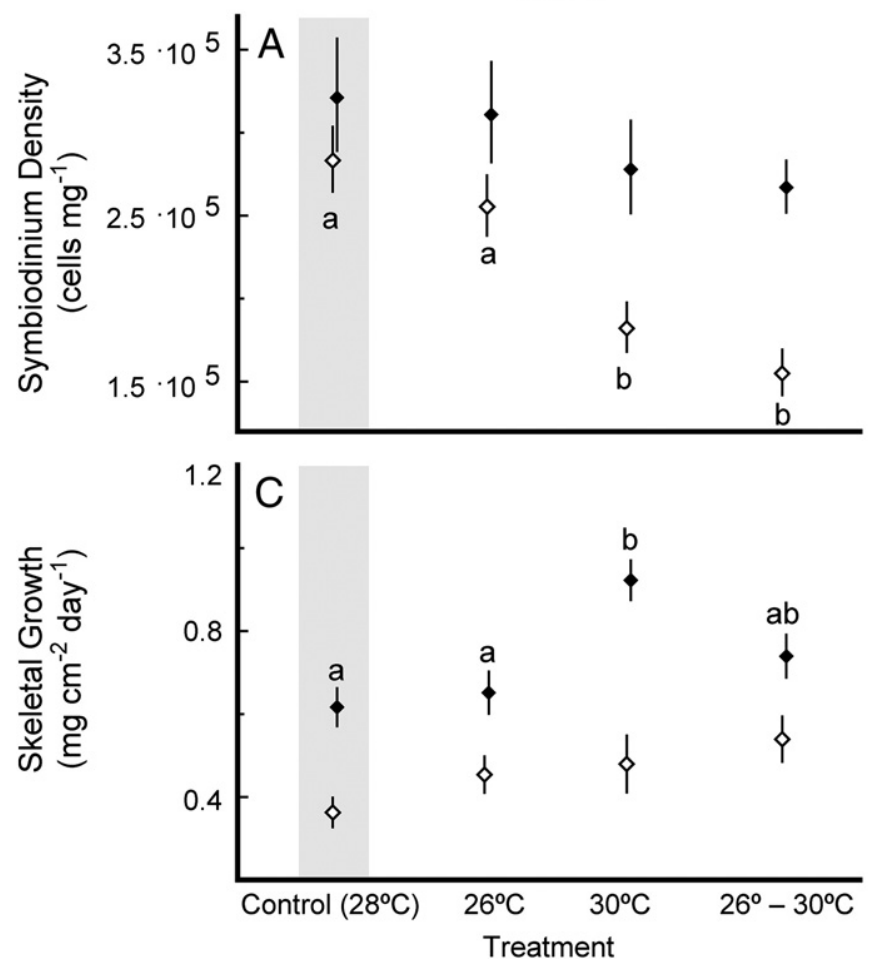

Trial 2

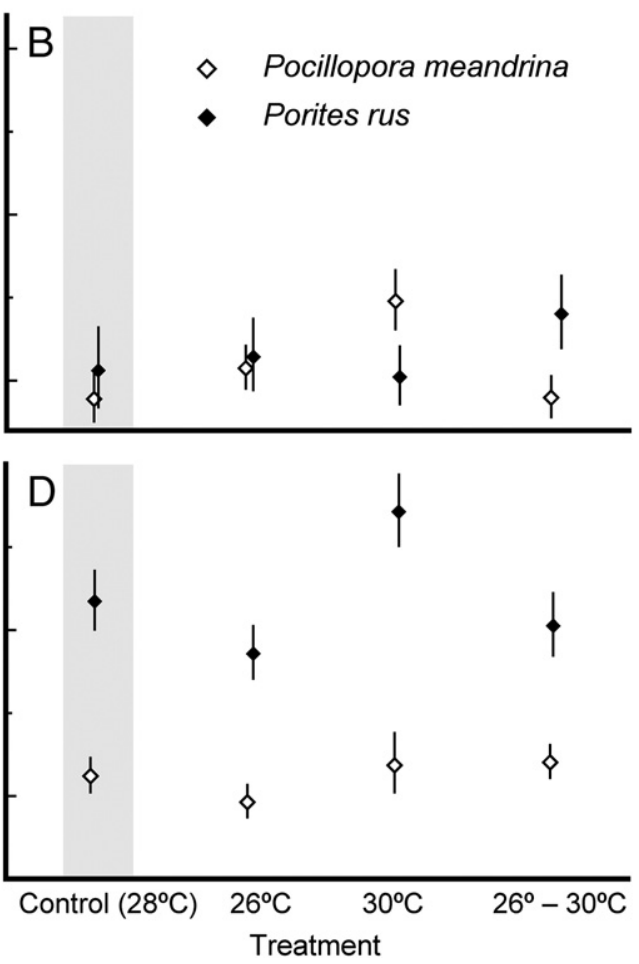

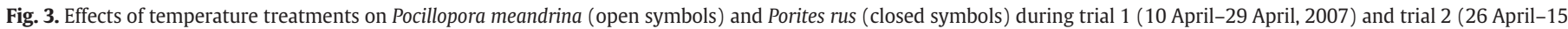

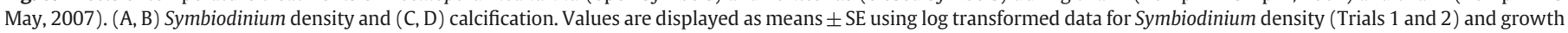

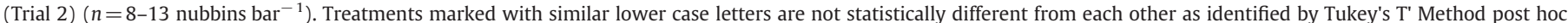

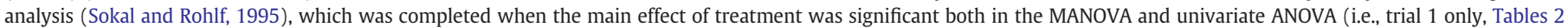
and 3). Shaded area denotes the control treatment $\left(28^{\circ} \mathrm{C}\right)$.

Trial 1

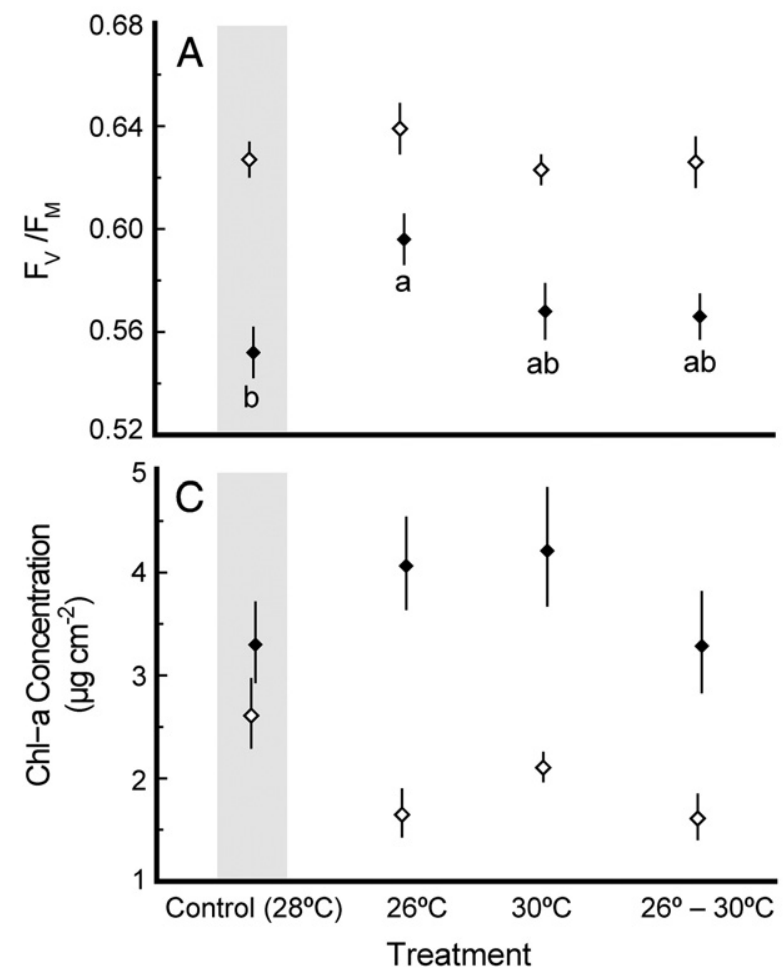

Trial 2

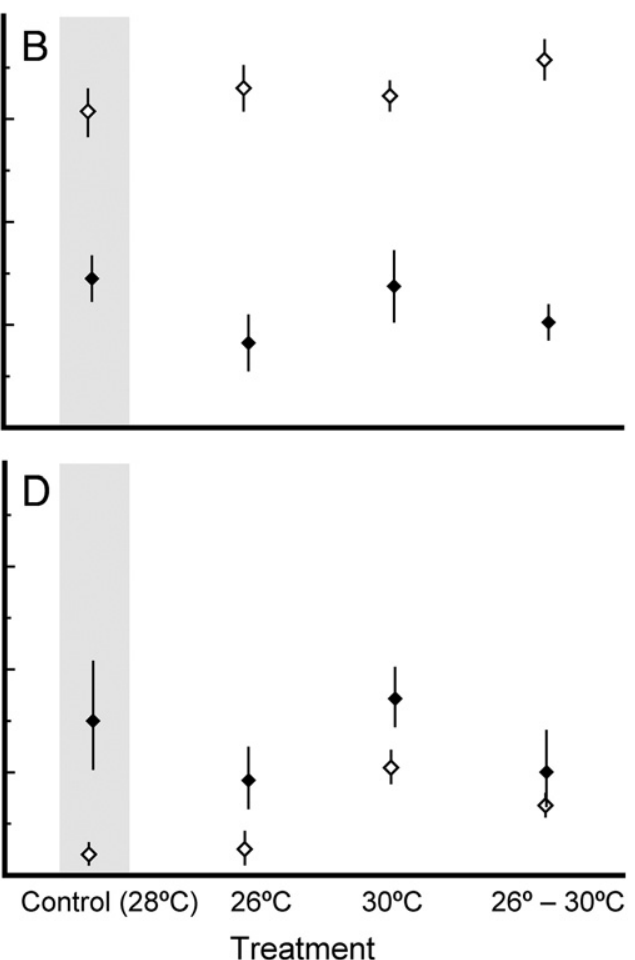

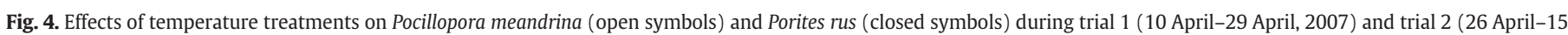

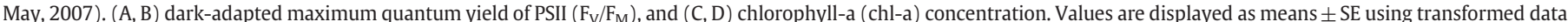

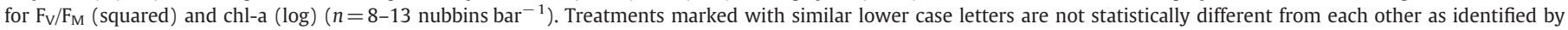

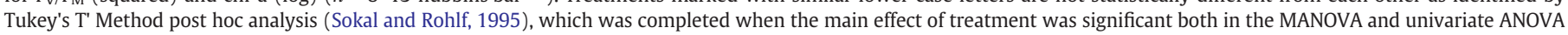
(i.e., trial 1, Tables 2 and 3). Shaded area denotes the control treatment $\left(28^{\circ} \mathrm{C}\right)$. 


\subsubsection{Holobiont-related response variables}

Mean calcification ranged from 0.36 to $0.54 \mathrm{mg} \mathrm{cm}^{-2}$ day $^{-1}$ for P. meandrina, and from 0.62 to $0.93 \mathrm{mg} \mathrm{cm}^{-2}$ day $^{-1}$ for P. rus (Fig. 3). Calcification differed significantly among treatments, with the effect driven by $P$. rus, for which the highest rates occurred in the steady $30{ }^{\circ} \mathrm{C}$ treatment, which differed from the $26{ }^{\circ} \mathrm{C}$ treatment and control $\left(28^{\circ} \mathrm{C}\right.$ ) (Fig. 3). However, calcification in the fluctuating treatment did not differ significantly from any other treatment. Conversely, calcification of $P$. meandrina was unaffected by the treatments. Overall the mean calcification of $P$. rus was $1.6 \times$ higher than for $P$. meandrina, and this resulted in the significant species effect for this variable, but did not result in a treatment $\times$ species interaction (Table 3 ).

\subsection{Trial 2}

Again in trial 2, the corals remained healthy in appearance with only slight paling recorded in the treatments. MANOVA revealed no clear effect of the treatments, however the species effect was significant (Table 2), as in trial 1. Although the main factor of treatment was not significant in the MANOVA, exploratory univariate ANOVAs were completed to support a qualitative contrast of the outcomes of trials 1 and 2; results presented for trial 2 focus on the univariate analyses of the main effect of species.

\subsubsection{Symbiont-related response variables}

Symbiont density was not affected significantly by species, or the interaction of the main effects (Table 3). However, treatmentaveraged densities of Symbiodinium were $\sim 23 \%$ lower in P. meandrina in trial 2 compared to trial 1 , and $\sim 43 \%$ lower in P. rus in trial 2 compared to trial 1. Following treatments, $\mathrm{F}_{\mathrm{V}} / \mathrm{F}_{\mathrm{M}}$ for P. rus was $10-15 \%$ lower across treatments in comparison to $\mathrm{F}_{\mathrm{V}} / \mathrm{F}_{\mathrm{M}}$ for $P$. meandrina (Fig. 4), but was unaffected by the treatment $\times$ species interaction (Table 3). Similar to trial 1, chl-a content differed between species $(F=18.476, d f=1,79, P<0.001) ; P$. meandrina had $\sim 1.5 \times$ less chl-a than $P$. rus (Fig. 4). Notably, chl-a content of $P$. rus and P. meandrina was reduced $62 \%$ and $19 \%$, respectively, in trial 2 compared to trial 1.

\subsubsection{Holobiont-related response variables}

Calcification in each treatment was similar between trial 1 and trial 2 (Fig. 3). In trial 2, there was a significant effect of species, but not of the treatment $\times$ species interaction (Table 3 ). The species effect was created by the $\sim 2$-fold greater average calcification in $P$. rus compared to $P$. meandrina.

\section{Discussion}

Our study was motivated by the observation that coral communities can flourish in thermally unstable habitats (Craig et al., 2001; Lee et al., 1999; Leichter et al., 2006; Sheppard, 2009), including the back reef of Moorea, and had the objective of contrasting the effects of fluctuating and steady temperatures on two species of corals. We went to great lengths to create fluctuating temperature treatments with temporal replication, but the logistical challenges of this task resulted in a time effect preventing an analysis replicated in time. We cannot be certain what caused this effect, but the identical conditions in the two trials supports the conclusion that the corals differed in their responses because they had dissimilar histories on the reef prior to collection.

The results of the first trial demonstrate that fluctuating temperatures $\left(4^{\circ} \mathrm{C}\right.$ amplitude at $11.5 \mu \mathrm{Hz}$ ) resulted in a decline of Symbiodinium density in $P$. rus and $P$. meandrina relative to the control and the steady $26{ }^{\circ} \mathrm{C}$ treatment. Similar declines also occurred in the steady $30{ }^{\circ} \mathrm{C}$ treatment. The largest reductions in Symbiodinium densities in our study (13-45\%) are characteristic of thermal bleaching (Fitt et al., 2001), yet other Symbiodinium parameters were largely unaffected, and calcification was maintained or slightly enhanced. Unlike the results of our study, naturally occurring thermal bleaching typically involves depressed photophysiology and chlorophyll content, and impaired holobiont growth (Porter et al., 1989; Fitt et al., 2001; Goreau and Macfarlane, 1990). While it is possible that such effects were not expressed in our experiment due to its duration (13 days), it is surprising that $\mathrm{F}_{\mathrm{v}} / \mathrm{F}_{\mathrm{m}}$ was unaffected by exposure to $30^{\circ} \mathrm{C}$, as this metric is usually sensitive to thermal stress within only a few hours (Jones et al., 1998). Perhaps in the present case, the reduction in Symbiodinium density was a product of a process similar to "animal stress bleaching" (sensu Fitt et al., 2001), which is thought to be characteristic of rapid and large changes in temperature (Fitt et al., 2001), as employed in our study, and involves the expulsion of oral endoderm cells containing viable Symbiodinium (Gates et al., 1992; Fitt et al., 2001). However, this is challenging to reconcile with the absence of an effect on calcification, but perhaps growth effects would be evident over a longer experimental duration. Regardless of the underlying mechanism, our study demonstrates that an ecologically relevant fluctuating thermal regime has effects on corals that are comparable to those resulting from continuous exposure to $30^{\circ} \mathrm{C}$. It is unknown why cyclic exposure to a maximum of $30^{\circ} \mathrm{C}$ for such a short period elicits such a strong effect, but this outcome could result from one or more of the following: 1) the time spent at the elevated temperature, 2) the juxtaposition of rapid and cyclical exposures to low and high temperature, or 3 ) the rate of transition between the temperatures (e.g., Middlebrook et al., 2010). Elucidating the importance of each of these thermal signals will require experiments more complex than the one utilized here, and should utilize corals that are naïve with regard to historic exposure to fluctuating temperatures.

The response of $P$. meandrina and $P$. rus to fluctuating temperatures in trial 1 demonstrated that corals found naturally in thermally unstable conditions are responsive to such conditions during experimental manipulation, although this does not involve calcification (i.e., an aspect of growth), which is related to fitness in corals. It is possible that there were other effects of fluctuating temperatures, for although the treatment contrast was significant for three of the four variables measured, post hoc analyses detected only one difference between the control and the fluctuating treatment (i.e., Symbiodinium density in P. meandrina). The mean densities of Symbiodinium in P. rus, as well as calcification and $\mathrm{F}_{\mathrm{v}} / \mathrm{F}_{\mathrm{m}}$ for both species, suggest that these variables might also have changed under fluctuating conditions in trial 1. Declines in Symbiodinium density can be expected to affect the capacity for autotrophy, nutrient recycling, and light-dependent calcification (Muller-Parker and D'Elia, 1997), with the implications accentuated with greater declines in Symbiodinium density, eventually resulting in death (Jokiel and Coles, 1990; Szmant and Gassman, 1990; Fitt et al., 2001; Rodrigues and Grottoli, 2007). Contrasts of the present results with comparable studies employing steady thermal stress for similar durations indicate that the losses of Symbiodinium reported here are large. For instance, Symbiodinium densities in P. damicornis declined $\sim 10-20 \%$ after 2 weeks at $30{ }^{\circ} \mathrm{C}$ in Panama (ambient $+2{ }^{\circ} \mathrm{C}$ ) (Glynn and D'Croz, 1990), and in P. damicornis from Australia, they declined $\sim 15-25 \%$ after 2 weeks at $29^{\circ} \mathrm{C}$ (ambient $+3{ }^{\circ} \mathrm{C}$ ) (Ulstrup et al., 2006). Against this backdrop, it is surprising that the collateral effects in the present study of exposure to fluctuating temperatures and $30{ }^{\circ} \mathrm{C}$ were small, and included calcification rates that remained within the range reported for congeners (Marubini and Davies, 1996; Edmunds, 2005, P.J. Edmunds unpublished data). As our study also demonstrates that dissimilar results can be generated from the same treatments in a different temporal context - for example in a consecutive trial (described below) - our findings from trial 1 are best interpreted as one of several possible outcomes of exposing back reef corals to fluctuating temperatures.

Perhaps most unexpected was the finding of large differences in the response of corals to treatments between the trials. We attempted to standardize the historic effect in our study by beginning our experiments with a 5-day incubation under steady conditions, although logistical constraints prevented an explicit test of the efficacy of this 
procedure. Trial 2 began 16 days after trial 1 using freshly collected corals, yet even though the treatments were identical, the outcomes differed; there was no multivariate effect of treatment, and the univariate ANOVAs revealed restricted effects of the treatments. Specifically, Symbiodinium density and $\mathrm{F}_{\mathrm{v}} / \mathrm{F}_{\mathrm{m}}$ were unaffected by the treatments, calcification was barely altered (P. rus), and chlorophyll-a was strongly affected ( $P$. meandrina). The most striking difference between trials was the reduction in Symbiodinium density $(\approx 50 \%)$ and chlorophyll-a content $(\approx 40 \%)$ in corals from the control treatment of trial 2 versus 1 . There were no signs of bleaching (i.e., difference in color) in trial 2 compared to trial 1, or among conspecifics on the back reef, and while the mean seawater temperature in this habitat reached $29.4^{\circ} \mathrm{C}$ throughout April 2007 (PJ Edmunds, unpublished data), such temperatures are common, as are transgressions to $>30^{\circ} \mathrm{C}$ (Fig. 1a). Thus, while the temperature in the back reef during April 2007 (when trial 2 was conducted) was close to the local threshold for bleaching $\left(\sim 29.8^{\circ} \mathrm{C}\right.$, http://coralreefwatch.noaa.gov), it was not unusually high, and probably did not pose a substantial physiological stress on the corals that grow there, as indicated by the similarity of $\mathrm{F}_{\mathrm{v}} / \mathrm{F}_{\mathrm{m}}$ between trials (Fig. 4). Although we cannot exclude the possibility that the corals were compromised by stress-related bleaching in trial 2, in part because coral color and Symbiodinium density can be uncoupled in the early stages of bleaching (Fitt et al., 2001), we suspect that the declines in Symbiodinium density reflected the onset of routine seasonal changes in algal populations (Brown et al., 1999; Fitt et al., 2000). Such changes can be rapid, and in the Caribbean coral Montastrea faveolata, for example, seasonal declines in Symbiodinium density can occur at $2.2 \times 10^{6}$ cells $\mathrm{cm}^{2}$ month $^{-1}$ in a non-bleaching year (i.e., when corals do not appear pale), which corresponds to a $44 \%$ reduction month ${ }^{-1}$ from the winter maximum (Fig. 1 in Fitt et al., 2000).

If our hypothesis regarding seasonal variation is correct, then routine temporal variation in the biology of $P$. meandrina and $P$. rus were the cause of the apparent environment $\mathrm{x}$ trial interaction, possibly overshadowing a treatment effect in trial 2. A priori, we assumed that the back reef environment in the Austral autumn was sufficiently constant to justify temporal replications as a means to replicate treatments whose complexity and expense precluded concurrent replication. While the physical appearance of the corals emboldened us in our approach (i.e., their color did not vary appreciably), it appears that the assertion of environmental constancy (and its impacts on biological processes) was incorrect. This outcome serves as a cautionary reminder of the importance of repeating experiments - and of working towards alleviating the limitations of pseudoreplication (Hurlbert, 1984) - even when the experiments are difficult to accomplish.

Despite the unforeseen environment $\times$ trial interaction that eroded the analytical capacity of our study, overall our experiment contributes to understanding the impacts of fluctuating thermal regimes on corals. The results of the two trials suggest that the response of back reef corals to oscillatory thermal environment may differ between periods when their tissues are well populated with, versus depleted of, Symbiodinium. When Symbiodinium densities are high, for example in the winter and spring (Brown et al., 1999; Fitt et al., 2000), corals are able to respond by reducing their Symbiodinium population in response to diurnal variations in temperature. This responsiveness may degrade, however, as Symbiodinium populations decline through seasonal effects concurrent with the end of summer and start of autumn (Brown et al., 1999; Fitt et al., 2000).

As our corals came from the thermally unstable back reef habitat, it is reasonable to hypothesize that this regime has led to an acquired resistance to thermal stress, as demonstrated by Barshis et al. (2010). Assuming that the back reef corals of Moorea are not genetically adapted to their environment on account of the frequent exchange of seawater with the outer reef (Hench et al., 2008), and the potential for connectivity among populations with pelagic larvae (Cowen and Sponaugle, 2009), resistance to thermal challenges in this habitat would be acquired through acclimatization and physiological plastic- ity (sensu Kingsolver and Huey, 1998). Without further research, such mechanisms remain a matter of speculation and are generally beyond the scope of what can be described in a study based on empirical results. Nevertheless, we are struck by the potential of one such mechanism to account for our results, and for this reason suspect it could be a productive subject of further experimental investigation. In short, it is intriguing to consider the possibility that a fluctuating thermal regime induces the reduction in Symbiodinium density within corals as a stress response, but thereafter this response leaves them well suited to adjust for the losses of their symbionts by up-regulating host metabolism. This might be accomplished by exploiting tissues reserves (Rodrigues and Grottoli, 2007), and/or alternative heterotrophic resources (Anthony and Fabricius, 2000), or by differentially exploiting the Symbiodinium remaining, and sustaining calcification through still poorly known linkages with photophysiology (Allemand et al., 2004).

\section{Acknowledgements}

This research was supported by funding from the National Science Foundation to the Moorea Coral Reef, Long-Term Ecological Research site (OCE 04-17412), gifts from the Gordon and Betty Moore Foundation, and grants from California State University Northridge's Graduate Studies, Research and International Programs, the University Corporation, and Associated Students. The study was completed under a French Polynesian Ministry of Research permit to PJE. The authors are grateful for generous assistance provided by the staff of the U.C. Berkeley Richard B. Gump South Pacific Research Station, M. Murray, and N. Muehllehner. The authors declare that they have no conflict of interest. This is a contribution of the MCR-LTER, and is contribution no. 167 of the CSUN marine biology program. [SS]

\section{References}

Allemand, D., Ferrier-Pagès, C., Furla, P., Houlbrèque, F., Puverel, S., Reynaud, S. Tambutté, E., Tambutté, S., Zoccola, D., 2004. Biomineralization in reef-building corals: from molecular mechanisms to environmental control. C.R. Palevol 3, 453-467.

Anthony, K.R.N., Fabricius, K.E., 2000. Shifting roles of heterotrophy and autotrophy in coral energetics under varying turbidity. J. Exp. Mar. Biol. Ecol. 252, 221-253.

Barshis, D.J., Stillman, J.H., Gates, R.D., Toonen, R.J., Smith, L.W., Birkeland, C., 2010 Protein expression and genetic structure of the coral Porites lobata in an environmentally extreme Samoan back reef: does host genotype limit phenotypic plasticity? Mol. Ecol. 19, 1705-1720.

Birkeland, C., Craig, P., Fenner, D., Smith, L., Kiene, W.E., Riegl, B.M., 2008. Geologic setting and ecological functioning of coral reefs in American Samoa. In: Riegl, B.M., Dodge, R.E. (Eds.), Coral Reefs of the USA. Springer, Netherlands, pp. 741-765.

Brown, B.E., 1997a. Coral bleaching: causes and consequences. Coral Reefs 16, S129-S138 (Suppl.).

Brown, B.E., 1997b. Adaptations of reef corals to physical environmental stress. Adv. Mar. Biol. 31, 221-299.

Brown, B.E., Dunne, R.P., Ambarsari, I., Le Tissier, M.D.A., Satapoomin, U., 1999. Seasonal fluctuations in environmental factors and variations in symbiotic algae and chlorophyll pigments in four Indo-Pacific coral species. Mar. Ecol. Prog. Ser. 191, 53-69.

Brown, B.E., Dunne, R.P., Goodson, M.S., Douglas, A.E., 2002. Experience shapes the susceptibility of a reef coral to bleaching. Coral Reefs 21, 119-126.

Castillo, K.D., Helmuth, B.S.T., 2005. Influence of thermal history on the response of Montastraea annularis to short-term temperature exposure. Mar. Biol. 148, 261-270.

Coles, S.L., 1997. Reef corals occurring in a highly fluctuating temperature environment at Fahal Island, Gulf of Oman (Indian Ocean). Coral Reefs 16, 269-272.

Coles, S.L., Brown, B.E., 2003. Coral bleaching - capacity for acclimatization and adaptation. Adv. Mar. Biol. 46, 183-223.

Coles, S.L., Jokiel, P.L., 1977. Effects of temperature on photosynthesis and respiration in hermatypic corals. Mar. Biol. 43, 209-216.

Cowen, R.K., Sponaugle, S., 2009. Larval dispersal and marine population connectivity Annu. Rev. Mar. Sci. 1, 443-466.

Craig, P., Birkeland, C., Belliveau, S., 2001. High temperatures tolerated by a diverse assemblage of shallow-water corals in American Samoa. Coral Reefs 20, 185-189.

Davies, P.S., 1989. Short-term growth measurements of corals using an accurate buoyant weighing technique. Mar. Biol. 101, 389-395.

D'Croz, L., Maté, J.L., 2004. Experimental responses to elevated water temperature in genotypes of the reef coral Pocillopora damicornis from upwelling and nonupwelling environments in Panama. Coral Reefs 23, 473-483. 
Dunn, S.R., Thomason, J.C., Le Tissier, M.D.A., Bythell, J.C., 2004. Heat stress induces different forms of cell death in sea anemones and their endosymbiotic algae depending on temperature and duration. Cell Death Differ. 11, 1213-1222.

Edmunds, P.J., 2005. The effect of sub-lethal increases in temperature on the growth and population trajectories of three scleractinian corals on the southern Great Barrier Reef. Oecologia 146, 350-364.

Edmunds, P.J., 2009. Effect of acclimatization to low temperature and reduced light on the response of reef corals to elevated temperature. Mar. Biol. 156, 1797-1808.

Edmunds, P.J., Leichter, J.J., Adjeroud, M., 2010. Landscape-scale variation in cora recruitment in Moorea, French Polynesia. Mar. Ecol. Prog. Ser. 414, 75-89.

Fabricius, K.E., 2006. Effects of irradiance, flow, and colony pigmentation on the temperature microenvironment around corals: implications for coral bleaching? Limnol. Oceanogr. 51, 30-37.

Fitt, W.K., McFarland, F.K., Warner, M.E., Chilcoat, G.C., 2000. Seasonal patterns of tissue biomass and densities of symbiont dinoflagellates in reef corals and relation to coral bleaching. Limnol. Oceanogr. 45, 677-685.

Fitt, W.K., Brown, B.E., Warner, M.E., Dunne, R.P., 2001. Coral bleaching: interpretation of thermal tolerance limits and thermal thresholds in tropical corals. Coral Reefs 20, 51-65.

Gates, R.D., Baghdasarian, G., Muscatine, L., 1992. Temperature stress causes host cell detachment in symbiotic cnidarians: implications for coral bleaching. Biol. Bull. $182,324-332$.

Genty, B., Briantais, J.-M., Baker, N.R., 1989. The relationship between the quantum yield of photosynthetic electron transport and quenching of chlorophyll fluorescence. Biochem. Biophys. Acta 990, 87-92.

Gleeson, M.W., Strong, A.E., 1995. Applying MCSST to coral reef bleaching. Adv. Space Res. 16, 151-154.

Glynn, P.W., D'Croz, L., 1990. Experimental evidence for high temperature stress as the cause of El Niño-coincident coral mortality. Coral Reefs 8, 181-191.

Gorbunov, M.Y., Kolber, Z.S., Lesser, M.P., Falkowski, P.G., 2001. Photosynthesis and photoprotection in symbiotic corals. Limnol. Oceanogr. 46, 75-85.

Goreau, T.J., Macfarlane, A.H., 1990. Reduced growth rate of Montastrea annularis following the 1987-1988 coral-bleaching event. Coral Reefs 8, 211-215.

Hench, J.L., Leichter, J.J., Monismith, S.G., 2008. Episodic circulation and exchange in a wave-driven coral reef and lagoon system. Limnol. Oceanogr. 53, 2681-2694.

Hoegh-Guldberg, O., Smith, G.J., 1989. The effect of sudden changes in temperature light and salinity on the population density and export of zooxanthellae from the reef corals Stylophora pistillata Esper and Seriatopora hystrix Dana. J. Exp. Mar. Biol. Ecol. 129, 279-303.

Hurlbert, S.H., 1984. Pseudoreplication and the design of ecological field experiments. Ecol. Monogr. 54, 187-211.

IPCC, 2007. Climate Change 2007: The Physical Science Basis. Contribution of Working Group I to the Fourth Assessment Report of the Intergovernmental Panel on Climate Change. Cambridge University Press, Cambridge, UK and New York.

Jeffrey, S.W., Humphrey, G.F., 1975. New spectrophotometric equations for determining chlorophylls a, b, cl and c2 in higher plants, algae and natural phytoplankton. Biochem. Physiol. Pflanz. 167, 191-194.

Jimenez, I.M., Kühl, M., Larkum, A.W.D., Ralph, P.J., 2008. Heat budget and thermal microenvironment of shallow-water corals: do massive corals get warmer than branching corals? Limnol. Oceanogr. 53, 1548-1561.

Jokiel, P.L., Coles, S.L., 1990. Response of Hawaiian and other Indo-Pacific reef corals to elevated temperature. Coral Reefs 8, 155-162.
Jones, R.J., Hoegh-Guldberg, O., Larkum, A.W.D., Schreiber, U., 1998. Temperatureinduced bleaching of corals begins with impairment of the $\mathrm{CO}_{2}$ fixation mechanism in zooxanthellae. Plant Cell Environ. 21, 1219-1230.

Kingsolver, J.G., Huey, R.B., 1998. Evolutionary analyses of morphological and physiological plasticity in thermally variable environments. Am. Zool. 38, 545-560.

Lee, H.-J., Chao, S.-Y., Fan, K.-L., Kuo, T.-Y., 1999. Tide-induced eddies and upwelling in a semi-enclosed basin: Nan Wan. Estuar. Coast. Shelf Sci. 49, 775-787.

Leichter, J.J., Helmuth, B., Fisher, A.M., 2006. Variation beneath the surface: quantifying complex thermal environments on coral reefs in the Caribbean, Bahamas and Florida. J. Mar. Res. 64, 563-588.

Marsh, J.A., 1970. Primary productivity of reef-building calcareous red algae. Ecology 51, 255-263.

Marubini, F., Davies, P.S., 1996. Nitrate increases zooxanthellae population density and reduces skeletogenesis in corals. Mar. Biol. 127, 319-328.

McClanahan, T.R., Maina, J., 2003. Response of coral assemblages to the interaction between natural temperature variation and rare warm-water events. Ecosystems 6 , 551-563.

McClanahan, T.R., Ateweberhan, M., Muhando, C.A., Maina, J., Mohammed, M.S., 2007. Effects of climate and seawater temperature variation on coral bleaching and mortality. Ecol. Monogr. 77, 503-525.

Middlebrook, R., Hoegh-Guldberg, O., Leggat, W., 2008. The effect of thermal history on the susceptibility of reef-building corals to thermal stress. J. Exp. Biol. 211, 1050-1056.

Middlebrook, R., Anthony, K.R.N., Hoegh-Guldberg, O., Dove, S., 2010. Heating rate and symbiont productivity are key factors determining thermal stress in the reefbuilding coral Acropora formosa. J. Exp. Biol. 213, 1026-1034.

Muller-Parker, G., D'Elia, C.F., 1997. Interactions between corals and their symbiotic algae. In: Birkeland, C. (Ed.), Life and Death of Coral Reefs. Chapman and Hall, New York, pp. 96-113. 536 pp.

Porter, J.W., Fitt, W.K., Spero, H.J., Rogers, C.S., White, M.W., 1989. Bleaching in reef corals: physiological and stable isotopic responses. Proc. Natl. Acad. Sci. 86, 9342-9346.

Quinn, G.P., Keough, M.J., 2002. Experimental Design and Data Analysis for Biologists. Cambridge University Press, Cambridge.

Rodrigues, L.J., Grottoli, A.G., 2007. Energy reserves and metabolism as indicators of coral recovery from bleaching. Limnol. Oceanogr. 52, 1874-1882.

Sheppard, C., 2009. Large temperature plunges recorded by data loggers at different depths on an Indian Ocean Atoll: comparison with satellite data and relevance to coral refuges. Coral Reefs 28, 399-403.

Sokal, R.R., Rohlf, F.J., 1995. Biometry: The Principles and Practice of Statistics in Biological Research. W.H. Freeman and Company, New York.

Szmant, A.M., Gassman, N.J., 1990. The effects of prolonged "bleaching" on the tissue biomass and reproduction of the reef coral Montastrea annularis. Coral Reefs 8, 217-224.

Ulstrup, K.E., Berkelmans, R., Ralph, P.J., van Oppen, M.J.H., 2006. Variation in bleaching sensitivity of two coral species across a latitudinal gradient on the Great Barrier Reef: the role of zooxanthellae. Mar. Ecol. Prog. Ser. 314, 135-148.

Warner, M.E., Fitt, W.K., Schmidt, G.W., 1999. Damage to photosystem II in symbiotic dinoflagellates: a determinant of coral bleaching. Proc. Natl. Acad. Sci. 96, 8007-8012.

Winter, A., Appeldoorn, R.S., Bruckner, A., Williams, E.H. Goenaga, C., 1998. Sea surface temperatures and coral reef bleaching off La Parguera, Puerto Rico (northeastern Caribbean Sea). Coral Reefs 17, 377-382. 